J. Perinat. Med. 3 (1975) 204

0.

\section{Cerebrospinal fluid studies in an intensive care nursery}

\author{
Marilyn Escobedo, Leslie L. Barton, Joseph Volpe
}

Edward Mallinckrodt Department of Pediatrics, Washington University School of Medicine, Divisions of Neonatology, Infectious Diseases, and Neurology, St. Louis Children's Hospital
Examination of the cerebrospinal fluid (CSF) of the neonate is frequently performed, yet fraught with difficulties in interpretation. Relatively high values for protein and cell number in the neonatal CSF are often attributed to traumatic entry of blood into the CSF during the procedure or to increased "meningeal permeability". There are few complete studies on the CSF of normal full term infants $[4,7,9]$, even fewer investigations on the fluid of premature infants $[2,3,6,7]$, and virtually no systematic observations of the protein, glucose and cellular content of the CSF in neonates admitted to a neonatal intensive care unit. In addition, the diagnosis of prematurity in previous studies was based on a birth weight of less than 2500 grams, and thus the possible influence of gestational age was overlooked.

The present paper reports the glucose, protein and cellular content of the CSF in infants of all gestational age categories referred to a neonatal intensive care unit and relates these findings to the illnesses characteristic of the neonatal period. We also test the hypothesis that the wide range of CSF alterations reported previously in normal infants is related, in part, to patient heterogeneity.

\section{Materials and methods}

Retrospective data were collected by examining the charts of the 1,070 infants admitted to the neonatal intensive care unit at St. Louis Children's Hospital from October, 1969, through October, 1972. For each of the 343 lumbar punctures performed, the number of red blood cells (RBCs),

\section{Curriculum vitae}

Dr. Escobedo was born in San Antonio, Texas, on February 26, 1945, and was graduated from Baylor University, Ŵaco, Texas, in 1966. She received ber $M$. D. from Washington University $\mathrm{Me}$ dical School, St. Louis, Missouri, in 1970. Her pediatric residency was completed at St. Louis Children's Hospital,

St. Louis, Missouri, where she also worked as a Fellow in Neonatology. She is now a Research Associate at Vanderbilt University, Nashville, Tennessee. Her work bas concerned the relationship of byperbilirubinemia to infection in the newborn, the continuous monitoring of arterial oxygen tension in neonates, the prognosis of neonatal seizures, the use of visually evoked electroencephalographic responses in the evaluation of cerebral function in neonates, and the induction of pulmonary maturity in lambs by epithelial growth factor.

white blood cells (WBCs), percentage of polymorphonuclear leukocytes (PMNs), protein, and glucose in the CSF, as well as the corresponding blood glucose were recorded. Results of bacterial and viral cultures were noted. Data gathered on each infant included the age in days at the time of the CSF examination, birth weight, estimated gestational age by physical examination [8], classification into a combined gestational ageweight category [1], mode of delivery, presentation (cephalic or breech), and the primary illness. The examiner's evaluation of the lumbar puncture as traumatic or atraumatic was also recorded. 


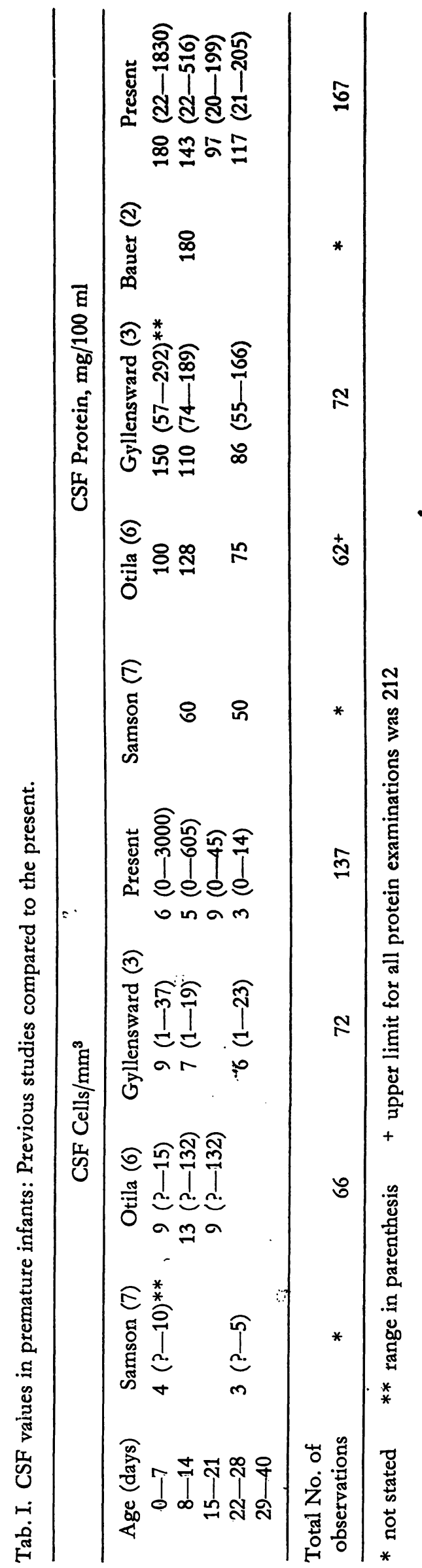

Prospective data were collected on 51 CSF examinations performed from January through April, 1973, in the same intensive care unit. The information collected was the same in both groups with the addition of the type of needle (long-bevel vs. short-bevel) used for lumbar puncture in the prospective group.

\section{Results}

Infants in the prospective study had an average birth weight of 2100 grams and an average estimated gestational age of $35-36$ weeks. The average birth weight of infants in the rctrospective group was 2600 grams and the average gestational age was $36-37$ wceks. There were no significant differences between the retrospective and prospective study groups with respect to either these parameters or the CSF glucose, protein and cell count. The data from both study groups were thus combined for all further analyses. Geometric, rather than arithmetic, means were used except when specified, because the former more closely represented the central tendency when the data had a skewed distribution.

Premature infants (estimated gestational age 37 weeks or less) were divided into groups based on age at the time of CSF examination. The average number of WBCs $/ \mathrm{mm}^{3}$ found in the fluid was 6 in the first week, 5 in the second, 9 in the third, and 3 in the fourth (Tab. I). The range is largest in the first week of life $(0-3,000)$ and becomes smaller in the fourth week (0-14). Protein concentration in the CSF follows the same trend with a mean of $180 \mathrm{mg} / 100 \mathrm{ml}$ (range 22-1830) in the first week and $117 \mathrm{mg} /$ $100 \mathrm{ml}$ (range 21-205) in the fourth week (Tab. I).

Term infants (estimated gestational age 38 weeks or more) were also grouped by age at the time of initial lumbar puncture. Their cerebrospinal fluids contained an average of 5 WBCs/ $\mathrm{mm}^{3}$ in the first week (range 0-1980) and 5 in the fourth week (range 0-60), (Tab. II). The mean protein concentration was $117 \mathrm{mg} / 100 \mathrm{ml}$ in the first week (range 18-244) and $74 \mathrm{mg} /$ $100 \mathrm{ml}$ in the fourth week (range 25-162) (Tab. II). 


\subsection{Results of bacterial and viral cultures}

A virus or bacteria was cultured from 15 (4\%) of the 394 specimens. Five yielded E. coli, six group B beta hemolytic streptococci, and one each a pneumococcus, cytomegalovirus, Coxsackie and ECHO virus. The reasons for performing the lumbar puncture were compared to the culture results. Numbers were not large enough to achieve statistical significance. However, of the 37 cerebrospinal fluid examinations accomplished because of neonatal gastrointestinal symptoms (vomiting, diarrhea, abdominal distention, poor feeding), and of the 32 cerebrospinal fluids examined because of premature rupture of membranes, amnionitis, or maternal fever, none were culturally positive. On the other hand, of the 55 patients in whom the CSF was examined because of temperature instabilitỹ, 4 (7\%\%) yiëlded a viral or bacterial isolate. Lumbar puncture was performed in the eleven other patients with documented infection of the CSF because of cardiorespiratory symptoms in four, neurologic symptoms in three, hyperbilirubinemia in one and for unspecified reasons in three patients.

\subsection{Relations to primary diagnosis}

The CSF protein concentration was significantly $(p<0.001)$ related to weight, gestational age, and primary diagnosis (Tab. III, Fig. 1). The highest values were found in infants with intracranial hemorrhage (subarachnoid and intraventricular), infants with bacterial meningitis, and infants of diabetic mothers. The CSF protein concentration tended to fall with advancing gestational and with increasing weight except for infants weighing more than 3500 grams (Fig. 1).

The mean CSF glucose concentration was $59 \mathrm{mg} / 100 \mathrm{ml}$; the corresponding mean blood glucose was $92 \mathrm{mg} / 100 \mathrm{ml}$ (arithmetic means). The ratio of glucose concentration in the CSF to that in the blood was not significantly related to weight, gestational age, or combined gestational age-weight categories; nor was it related to mode of delivery, presentation, primary diagnosis, or whether the tap was traumatic or atraumatic. However, small for gestational age infants of all ages tended to have higher glucose 
Tab. III. The CSF cell and protein content related to diagnosis.

\begin{tabular}{lcrr}
\hline \multicolumn{1}{c}{ Diagnosis } & No. of WBCs $/ \mathrm{mm}^{3}$ & No. of RBCs/mm & CSF Protein, $\mathrm{mg} / 100 \mathrm{ml}$ \\
\hline Documented Infection*** & $12(47)^{*}$ & $53(46)$ & $101(50)$ \\
Bacterial Meningitis & $448(6)$ & $151(6)$ & $160(7)$ \\
Intracranial Hemorrhage & $10(24)$ & $1.151(26)$ & $170(36)$ \\
Infants of Diabetic Mothers & $30(10)$ & $939(9)$ & $198(12)$ \\
Pneumonia*** & $5(44)$ & $66(43)$ & $84(44)$ \\
Respiratory Distress Syndrome & $4(68)$ & $116(66)$ & $136(73)$ \\
Asphyxia & $4(6)$ & $45(7)$ & $133(7)$ \\
Hyperbilirubinemia & $3(31)$ & $45(32)$ & $116(31)$ \\
\hline
\end{tabular}

* no. of observations are in parenthesis

** includes viral and bacterial meningitis, bacterial sepsis, urinary tract infections, and gastroenteritis

*** documented by chest radiograph only

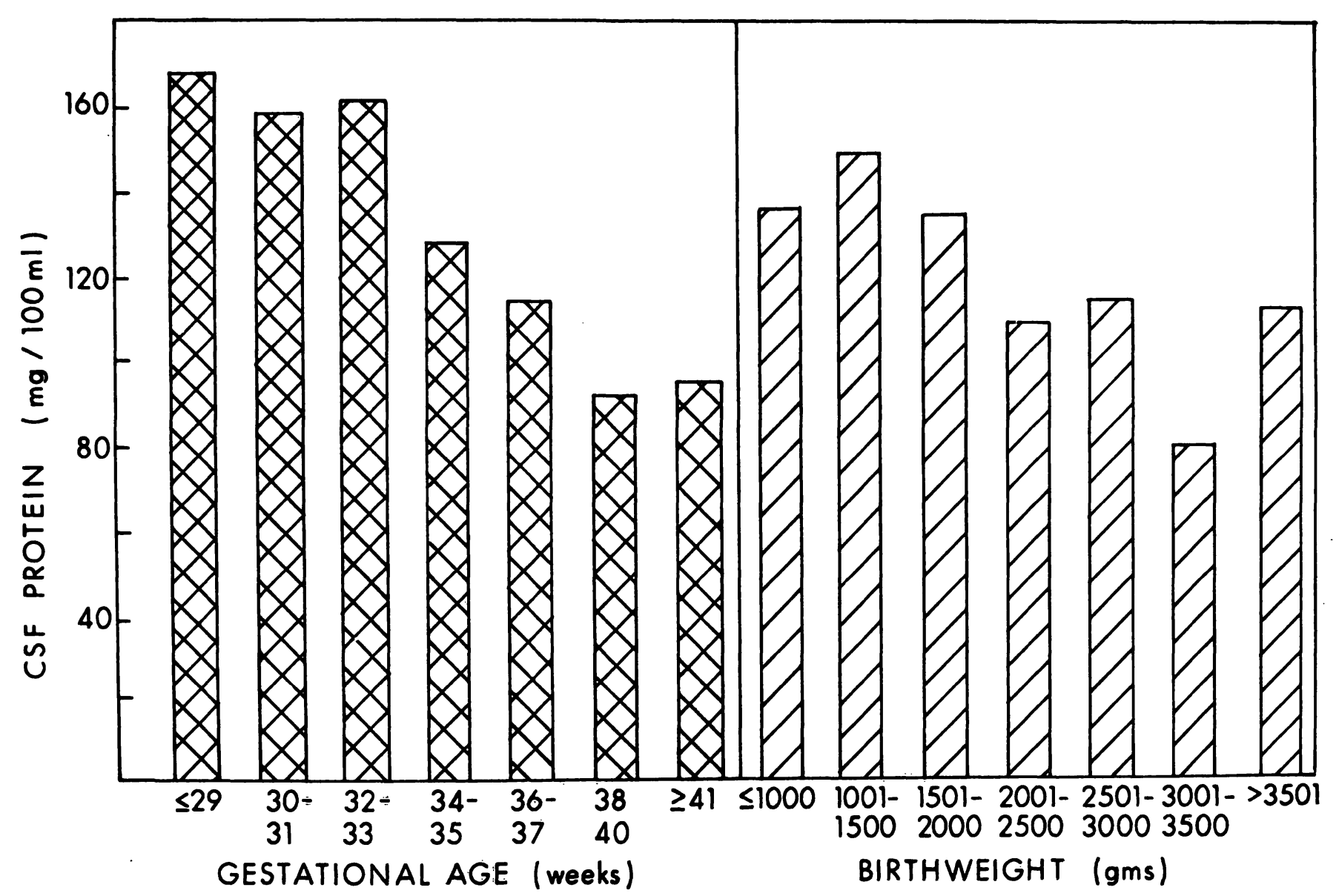

Fig. 1. Mean values for CSF protein related to gestational age and birthweight.

ratios (0.9 to 1.0 ) than large or appropriate for gestational age infants (0.6 to 0.8$)$. .

A significant relationship $(\mathrm{p}<0.006)$ was found between the number of WBCs in the CSF and the primary diagnosis (Tab. III). The infants with bacterial meningitis, intracranial hemorrhage, and those born of diabetic mothers had the highest numbers. In contrast, the three infants with viral isolates from the CSF had a mean of $2 \mathrm{WBCs} / \mathrm{mm}^{3}$ and $38 \mathrm{mg} / 100 \mathrm{ml}$ protein in their CSF. Neither the number of WBCs nor the percentage of PMNs in the CSF was significantly related to weight, gestational age, combined gestational age-weight categories, mode of delivery, or 
presentation. The highest percentage of PMNs in the CSF was seen in infants with bacterial meningitis (Tab. III).

\subsection{Relations to final diagnosis}

The number of RBCs was significantly related to the final diagnosis (Tab. III), the highest values being found in infants with intracranial hemorrhage and those born of diabetic mothers. No significant relationship was found between the number of $\mathrm{RBCs}$ and weight, gestational age, combined weight-gestational age categories, mode of delivery, or presentation.

There were obvious differences between the number of RBCs, WBCs, and concentration of protein derived from traumatic versus atraumatic taps, after infants with intracranial hemorrhage iwere removed from the atraumatic group. For example, a mean value of $1,541 \mathrm{RBCs} / \mathrm{mm}^{3}$ was found in traumatic taps compared to a mean of $30 \mathrm{RBCs} / \mathrm{mm}^{3}$ in atraumatic taps (excluding infants with intracranial hemorrhage).

Five of thirty lumbar punctures done with a long-bevel needle (\#23 venipuncture) and two of sixteen lumbar punctures done with a shortbevel needle (\#22 spinal or \#23 scalp-vein) were traumatic.

\section{Discussion}

Difficulty in the interpretation of the CSF findings in neonates is chiefly due to the wide range of values which has been considered normal (Tabs. I and II). These values are the results of small number of studies of which only few have utilized the rigorous diagnostic and therapeutic techniques currently employed in neonatal intensive care units. The interpretation of the studies in premature infants is further hampered by a definition of prematurity based only on weight, or by the lack any published definition at all.

The present investigation derives its data from a group of infants, referred to an intensive care unit, all of whom had one or more illnesses. When the CSF findings are compared to the published normals (Tabs. I and II) there are no apparent differences in numbers of WBCs $/ \mathrm{mm}^{3}$ in premature or term infants, and none or only slight differences in the CSF protein concentration for prematures. This suggests that as in the present study, previous series must have had some degree of patient heterogeneity. Term infants in the present study tended to have higher CSF protein concentrations than previously published normals. The reason for this is unclear but may relate to the infant's primary diseases (see below).

Although this study was not an effort to redefine the normal values for the CSF in infants, it is apparent that increasing age at the time of lumber puncture was associated with decreasing cell number and lower protein values in the CSF. In fact, many of these values fell within the range considered normal for older children and adults [5]. Almost one-third (98 of 310) of both premature and full term infants had $0-1 \mathrm{WBC} / \mathrm{mm}^{3}$ in the CSF during the first three weeks of life. By the fourth week, one-half (8 of 17) of the premature and two-thirds (11 of 16) of the term infants had $0-1 \mathrm{WBC} / \mathrm{mm}^{3}$ in the CSF. Six of the twenty-seven premature and term infants had protein concentration $<40 \mathrm{mg} /$ $100 \mathrm{ml}$ in the third week of life. The values of CSF protein, RBCs, and WBCs correlated significantly with the infant's primary disease (Tab. III). Highest values for CSF protein concentration were found in infants with bacterial meningitis, intracranial hemorrhage and those born of diabetic mothers. The highest WBC values in the CSF were found in infants with these same diagnoses.

The factors underlying the CSF formulae relate in large part to the infant's primary disease and may be obvious (e. g., direct infection by bacterial or viral agents, irritation by blood and/or blood products). Lumbar punctures were performed in the infants born of diabetic mothers for a variety of indications ranging from hyperbilirubinemia to apnea and fever. The factors operative in producing CSF changes in these infants are unclear and deserve further study. Nevertheless, in this series of CSF examinations, it is apparent that well-established mechanisms for the production of meningeal inflammation are operative to produce most of the observed findings. Although our data do not rule out a role for changes in "meningeal permeability" 
in the production of CSF alterations in the newborn period (as has been usually postulated in previous studies), they do not support the notion that such changes are dominant.

\section{Summary}

Prospective and retrospective data were collected from 394 cerebrospinal fluid (CSF) examinations performed in premature and full term infants in a neonatal intensive care unit from October, 1969, to April, 1973. Premature infants had an average of $6 \mathrm{WBCs} / \mathrm{mm}^{3}$ and $180 \mathrm{mg} / 100 \mathrm{ml}$ protein in their CSF in the first week, and $3 \mathrm{WBCs} / \mathrm{mm}^{3}$ and $117 \mathrm{mg} / 100 \mathrm{ml}$ protein in the fourth week of life. Full term infants had an average of $5 \mathrm{WBCs} / \mathrm{mm}^{3}$ and $117 \mathrm{mg} /$ $100 \mathrm{ml}$ protein in the CSF during their first week, and $5 \mathrm{WBCs} / \mathrm{mm}^{3}$ and $74 \mathrm{mg} / 100 \mathrm{ml}$ protein in their fourth week of life. Thus, increasing age at the time of lumbar puncture was associated with decreased cell number and lower protein in the CSF.
Infants with bacterial meningitis, intracranical hemorrhage and those born of diabetic mothers had the highest values of CSF protein and WBCs. The highest number of RBCs in the CSF was seen in infants with intracranial hemorrhage and infants born of diabetic mothers.

Fifteen (4\%) of the 394 CSFs examined yielded a virus or bacteria: five $E$. coli, six group B beta hemolytic streptococci, and one each a pneumococcus, cytomegalovirus, Coxsackie, and ECHO virus.

The CSF findings in the population of infants afflicted with the variety of illnesses studied are not strikingly different from published "normals". Thus, some degree of patient heterogeneity must have been present in previous series.

Keywords: Bacterial meningitis, cerebrospinal fluid (CSF), intracranial hemorrhage, prematurity.

\section{Zusammenfassung}

Untersuchungen über den Liquor cerebrospinalis auf einer Neugeborenen-Intensivstation

Pro- und retrospektive Daten von 394 Gehirnflüssigkeitsproben wurden gesammelt. Die Analysen waren bei prämaturen und am Tragzeitende geborenen Kindern einer neonatalen Intensivstation in einem Zeitraum von Oktober 1969 bis April 1973 durchgeführt. Vor dem Tragzeitende geborene Kinder hatten eine mittlere Leukozytenzahl von $6 / \mathrm{mm}^{3}$ und $180 \mathrm{mg} / 100 \mathrm{ml}$ Protein in ihrem Liquor in der crsten Lebenswoche und $3 / \mathrm{mm}^{3}$ und $117 \mathrm{mg} / 100 \mathrm{ml}$ Protein in der 5. Lebenswoche. Ausgetragene Kinder hatten im Mittel 5 Leukozyten $/ \mathrm{mm}^{3}$ und $117 \mathrm{mg} / 100 \mathrm{ml}$ Eiweiß im Liquor während der ersten Woche und $5 / \mathrm{mm}^{3}$ und $74 \mathrm{mg} / 100 \mathrm{ml}$ Eiweiß in der 5. Lebenswoche. Man kann demzufolge feststellen, daß zunehmendes Alter bei der Lumbalpunktion mit einer herabgesetzten Zellzahl und einer niedereren Proteinkonzentration im Liquor einhergeht.
Die höchsten Werte an Liquorprotein und Zellgehalt fanden sich bei Kindern mit bakterieller Meningitis, intrakranieller Blutung und jenen, die von diabetischen Müttern geboren wurden. Höchste Anzahl an Erythrozyten im Liquor fanden sich bei Neugeborenen mit intrakranialer Blutung, bzw. bei Kindern von Müttern mit Diabetes mellitus. 15 (4\%) von 394 untersuchten Liquorproben ergaben eine virale oder bakterielle Besiedelung: in 5 Fällen E. coli, in 6 Fällen betahämolytische Streptokokken und je in einem Fall Pneumokokken, ZytomegaliVirus, Coxsackie-Virus und ECHO-Virus. Die Liquorbefunde in jener Gruppe von Neugeborenen, die mit einer Vielzahl von untersuchten Krankheiten behaftet war, unterschieden sich nicht auffallend von jenen Befunden, die als "normal" bekannt sind. Wir ziehen daraus den Schluß, daß in den früheren Untersuchungen ein gewisses $\mathrm{Ma} \beta$ von Heterogenität im Patientengut vorgelegen haben muß.

Schlüsselwörter: Bakterielle Meningitis, Liquor cerebrospinalis, intrakranielle Blutung, Prämaturität.

\section{Résumé}

Etude du liquide cephalo-rachidien dans une unité de surveillance intensive du nouveau-né

Des données prospectives et rétrospectives ont été rassemblées à partir de 394 examens de liquide céphalorachidien (L. C. R) réalisés sur une série de prématurés et d'enfants à terme d'une unité de surveillance intensive du nouveau-né d'Octobre 1969 à Avril 1973. Le liquide céphalo-rachidien des prématurés contenait en moyenne 6 globules blances $/ \mathrm{mm}^{3}$ et $180 \mathrm{mg} / 100 \mathrm{ml}$ de protéines à la première semaine et 3 globules blancs $/ \mathrm{mm}^{3}$ et $117 \mathrm{mg} /$ $100 \mathrm{ml}$ de protéines au cours de la 4émé semaine de vie. L.e liquide céphalo-rachidien des enfants à terme nomtrait en moyenne 5 globules blancs $/ \mathrm{mm}^{3}$ et $117 \mathrm{mg} / 100 \mathrm{ml}$ de protéines au cours de la première semaine et 5 globules blancs $/ \mathrm{Mm}^{3}$ et $74 \mathrm{mg} / 100 \mathrm{ml}$ de protéines au cours de la 4ème semaine. On constate donc une diminution des cellules et de la quantité de protéines avec l'âge de l'enfant.

Les enfants ayant présentés une méningite bactérienne, une hémorragie intra-cranienne ou ceux nés de mère diabétique avaient des valeurs très élevées de protéines et de globules blancs dans le liquide céphalo-rachidien. Les taux les plus élevés de globules rouges dans le liquide céphalo-rachidien furent observés chez les enfants ayant présentés une hémorragie intra-cranienne et chez ceux nés de mère diabètique.

Dans 15 des 394 cas (4\%) on putmettre en évidence un virus ou une bactérie: il s'agissait dans cinq cas d'E. 
COLI, dans six cas de streptoccoques beta hémolitique du groupe $B$ et dans un cas de pneumoccoque, de cytomégalovirus, de coxsackie, et de virus Echo.

Il n'existe pas de différence nette entre les résultats de l'étude des liquides céphalo-rachidien de notre population d'enfants pathologiques et ceux obtenus à partir de populations considérées comme normales. Il faut cependant penser que ces séries considérées comme normales devaient présenter un certain degré d'hétérogénéite du au patients.

Mots-clés: Hémorragie intra-cranienne, liquide céphalo-rachidien (LCRR), méningite bactérienne, prématurité.

\section{Acknowledgement}

We wish to thank Dr. Sung CHor for the statistical analysis of the data and Ms. Dolores Friesen for help in the preparation of the manuscript. Dr. Philip R. Dodge critically reviewed the manuscript.

\section{Bibliography}

[1] Battaglia, F., L. Lubchenko: A practical classification of newborn infants by weight and gestational age. J. Pediat. 71 (1967) 159

[2] Bauer, C., M. New, J. Miller: Cerebrospinal fluid protein values of premature infants. J. Pediat. 66 (1965) 1017

[3] Gyllensward, A., S. Malmstrom: The cerebrospinal fluid in immature infants. Acta Paediat. Suppl. 135 (1962) 54

[4] Nardoo, B.: The cerebrospinal fluid in the healthy newborn infant. S. Afr. Med. J. 42 (1968) 933

[5] Nelson, W., V. VaughN, R. McKay: Normal cerebrospinal fluid values. In: Textbook of Pediatrics. Saunders, Philadelphia 1969
[6] Otrla, E.: Studies on the cerebrospinal fluid in premature infants. Acta Paediat. Suppl. No. 8, 35 (1948) 5

[7] Samson, K.: Der normale Liquor Cerebrospinalis im ersten Lebenstrimenon. Z. ges. Neurol. Psychiat. 128 (1930) 494

[8] Usher, R., F. McLean, K. ScotT: Judgement of fetal age. II. Clinical significance of gestational age and an objective method for its assessment. Pediatr. Clin. N. Am. 13 (1966) 835

[9] WIdELL, S.: On the cerebrospinal fluid in normal children and in patients with acute abacterial meningoencephalitis. Acta Paediat. Suppl. 115 (1958) 5

\section{Dr. Leslie L. Barton}

St. Louis Children's Hospital

500 S. Kingshighway

St. Louis, Missouri 63110/USA 